\title{
Concentrations of progesterone and oxytocin receptors in endometrium of postpartum cows expected to have a short or normal oestrous cycle
}

\author{
W. G. Zollers, $\mathrm{Jr}^{1}{ }^{1}$, H. A. Garverick ${ }^{1} \dagger$, M. F. Smith ${ }^{1}$, R. J. Moffatt ${ }^{1}$, \\ B. E. Salfen ${ }^{1}$ and R. S. Youngquist ${ }^{2}$ \\ ${ }^{1}$ Departments of Animal Sciences and ${ }^{2}$ Veterinary Medicine and Surgery, University of Missouri, \\ Columbia, MO 65211, USA
}

\begin{abstract}
Luteal lifespan is short after first postpartum ovulation in early-weaned beef cows unless cows are pretreated with a progestogen. Regression of the short-lived corpus luteum in the postpartum beef cow is due to a premature release of prostaglandin $\mathrm{F}_{2 \alpha}\left(\mathrm{PGF}_{2 \alpha}\right)$ from the uterus. The premature release of $\mathrm{PGF}_{2 \alpha}$ may be mediated through lower concentrations of receptors for progesterone, higher concentrations of oxytocin receptors, or both, in the endometrium. Thirty-one beef cows were randomly assigned to four groups at parturition. Calves from cows assigned to the short cycle group ( $n=6$; control) and the short cycle/ endometrium group $(n=10)$ were weaned at 30-32 days post partum. Cows in the normal cycle group ( $n=5$; control) and the normal cycle/endometrium group $(n=10)$ received norgestomet implants for 9 days beginning 21-23 days post partum and calves were weaned at implant insertion. Duration of oestrous cycle $(x \pm$ SEM; $P<0.01)$ following first postpartum ovulation for the short cycle group was $11.5 \pm 1.9$ days compared with $18.8 \pm 0.6$ days for the normal cycle group. On day 5 following first postpartum ovulation, cows in the short cycle/endometrium and the normal cycle/endometrium groups were hysterectomized and endometrial tissue collected for measurement of progesterone and oxytocin receptors. Mean number of total progesterone receptors per cell was lower $(P<0.05)$ in the short cycle/endometrium group than in the normal cycle/endometrium group. Mean concentration of oxytocin receptors ( $\mathrm{fmol} \mathrm{mg} \mathrm{m}^{-1}$ protein) in the short cycle/endometrium group was higher $(P<0.05)$ than that in the normal cycle/endometrium group. In conclusion, uterine receptor populations for progesterone and oxytocin may influence the timing of $\mathrm{PGF}_{2 \alpha}$ secretion during short oestrous cycles.
\end{abstract}

\section{Introduction}

Subnormal luteal function has been associated with infertility in ruminants (for review see Garverick and Smith, 1986; Hunter, 1991; Lishman and Inskeep, 1991). Corpora lutea with short lifespans have been detected at puberty in cattle (GonzalezPadilla et al., 1975) and sheep (Berardinelli et al., 1980) and following the first postpartum ovulation in cattle (Odde et al., 1980). In anoestrous ewes, induced ovulation by treatment with GnRH is followed by subnormal luteal function (Haresign $e t$ al., 1975).

The following evidence indicates that the short luteal phase in cattle and sheep is due to a premature uterine secretion of prostaglandin $\mathrm{F}_{2 \alpha}\left(\mathrm{PGF}_{2 \alpha}\right)$ : (i) hysterectomy prevents regression of corpora lutea anticipated to have short lifespans in prepubertal ewe lambs (Keisler et al., 1983), anoestrous ewes (Southee et al., 1988) and postpartum cows (Copelin et al., 1987); (ii)

${ }^{*}$ Present address: University of Maryland School of Medicine, Physiology Department, Bressler Research Laboratories 11-016, 655 West Baltimore Street, Baitimore, MD 21201, USA.

†Reprint requests.

Received 21 February 1992. oxytocin induces a release of $\mathrm{PGF}_{2 a}$ in cattle on day 5 of a short but not a normal luteal phase (Zollers et al., 1989); (iii) basal and oxytocin-induced secretion of prostaglandins (in vitro) from bovine endometrium is greater on day 5 of a short compared with a normal luteal phase (Zollers $e t$ al., 1991); (iv) mean concentrations of $\mathrm{PGF}_{2 a}$ in the vena cava on days $4-9$ following first postpartum oestrus are higher in cows exhibiting a short compared with a normal oestrous cycle (Cooper ef al., 1991); (v) mean concentration of 15-keto-13,14-dihydroprostaglandin $\mathrm{F}_{2 a}$ (PGFM; the stable metabolite of PGF $_{2 \alpha}$ ) in plasma increases from day 3 to day 5 in ewes expected to have short oestrous cycles (Hunter et al., 1989); and (vi) active immunization of beef cows early post partum against PGF $_{2 \alpha}$ extends the lifespan of corpora lutea that are expected to be short-lived (Copelin et al., 1989).

McCracken et al. (1984) hypothesized that progesterone directly inhibits synthesis of uterine oxytocin receptors through the mid-luteal phase of a normal oestrous cycle. Declining progesterone dominance of the uterus near the end of the luteal phase may allow the synthesis of endometrial oxytocin receptors. Thus, the uterus becomes responsive to oxytocin and a positive feedback loop between $\mathrm{PGF}_{2 \alpha}$ and luteal oxytocin 
develops. This mechanism may ensure pulsatile secretion of $\mathrm{PGF}_{2 \alpha}$ to complete the process of luteal regression (Flint et al., 1990; Silvia et al., 1991).

In cows exhibiting a short oestrous cycle, decreased serum concentrations of oestradiol have been observed at oestrus compared with cows having a subsequent normal luteal phase (Garcia-Winder et al., 1986; Garverick et al., 1988). During a normal oestrous cycle, oestradiol from the preovulatory follicle may induce uterine progesterone receptors which are required to establish progesterone dominance of the uterus following subsequent ovulation (Ottobre et al., 1984). The decreased concentration of oestradiol observed at oestrus before a short luteal phase may therefore result in inadequate uterine progesterone receptor synthesis. Thus, the uterus may lose progesterone dominance earlier following ovulation. This would allow premature synthesis of oxytocin receptors and thereby initiate the positive feedback loop between oxytocin and $\mathrm{PGF}_{2 \alpha}$ earlier in the oestrous cycle. The purpose of this study was to investigate mechanisms involved in triggering uterine release of $\mathrm{PGF}_{2 \alpha}$ at an earlier time during the short luteal phase. Specifically, the objective was to determine concentrations of endometrial oxytocin and progesterone receptors on day 5 following the first postpartum oestrus in cows expected to have a short or normal luteal phase.

\section{Materials and Methods}

\section{Animals}

Thirty-one crossbred beef cows, expected to have short or normal oestrous cycles, were randomly assigned at parturition to four groups: short cycle ( $n=6$; control), short cycle/ endometrium $(n=10)$, normal cycle $(n=5 ;$ control) and normal cycle/endometrium $(n=10)$. All cows were in moderate to good body condition at calving. Cows in the normal cycle and normal cycle/endometrium groups received norgestomet implants (17 $\alpha$-acetoxy-11 $\beta$-methyl-19-nor pregn4-ene-3,20-dione; Sanofi Animal Health, Overland Park, KS) inserted into the ear for 9 days beginning 21-23 days post partum. Calves were weaned from cows in the short cycle and short cycle/endometrium groups at 30-32 days post partum and from cows in the normal cycle and normal cycle/endometrium groups at the time of implant insertion. Cows in the short cycle and normal cycle groups were used to verify that short cycles occurred in untreated animals and that norgestomet pretreatment resulted in a cycle of normal duration (Ramirez-Godinez et al., 1981).

Cows were observed for oestrus twice daily from parturition until the end of the experiment. Blood was collected from each cow via jugular venepuncture three times a week from parturition to weaning and then daily from weaning or implant removal to hysterectomy or second oestrus. Blood samples were kept at $4^{\circ} \mathrm{C}$ for $6-12 \mathrm{~h}$, and serum was harvested and frozen at $-20^{\circ} \mathrm{C}$ for subsequent measurement of progesterone. Concentration of progesterone in serum was determined by radioimmunoassay as previously described (Copelin et al., 1989). The intra-assay and interassay coefficients of variation were $12.1 \%$ and $11.4 \%$, respectively. Concentrations of progesterone were used to identify cows that ovulated prior to weaning, estimate the time of ovulation in animals that did not exhibit oestrus prior to first ovulation, and determine duration of luteal function and oestrous cycle duration in control animals. The first rise in serum concentration of progesterone was determined to be day 3 of the oestrous cycle. All control animals exhibited behavioural oestrus prior to their second postpartum ovulation.

\section{Tissue collection}

On day 5 following the first postpartum oestrus, cows in the short cycle/endometrium and normal cycle/endometrium groups were hysterectomized via midline incision. Cows were tranquillized by injecting (i.m.) $25 \mathrm{mg}$ xylazine (Haver Lockhart, Shawnee, KS) and $20 \mathrm{mg}$ acepromazine maleate (Fort Dodge Laboratories, Inc., Fort Dodge, IA, USA). Lidocaine hydrochloride (2\%; Tech America Group, Inc., Elwood, KS) was used as a local anaesthetic. After hysterectomy, the uterine horns were immediately placed on ice. Aliquots of endometrial tissue, containing caruncular and intercaruncular tissue, were removed from uterine horns within $10 \mathrm{~min}$ and rinsed in $0.9 \%$ saline. Endometrial samples were frozen in $3 \mathrm{~g}$ aliquots in liquid nitrogen and kept at $-80^{\circ} \mathrm{C}$ until contents of progesterone and oxytocin receptors were measured.

\section{Measurement of endometrial cyfosolic and nuclear progesterone receptors}

Preparation of cytosolic and nuclear fractions. The designations 'cytosolic' and 'nuclear' are defined experimentally, as described below. These terms are used to refer to the two main subcellular fractions into which progesterone receptors redistribute following homogenization of tissue in the buffers used. Our method of tissue preparation was not designed to maintain progesterone receptors at their point of origin (cytosol versus nucleus) in the cell. Various studies have demonstrated that progesterone receptors and other members of the steroid hormone superfamily reside predominantly in the nucleus in vivo (Gasc et al., 1984; King and Greene, 1984; Welshons et al., 1985). An aliquot of endometrium from each experimental animal was removed from storage at $-80^{\circ} \mathrm{C}$, chopped finely with scissors, and allowed to thaw on ice. All procedures were done at $4^{\circ} \mathrm{C}$ or on ice unless otherwise stated. Tissue was homogenized at a tissue:buffer ratio of $120 \mathrm{mg} \mathrm{ml}^{-1}$ in TEMG buffer $(10 \mathrm{mmol}$ Tris- $\mathrm{HCl} \mathrm{l} \mathrm{l}^{-1}, \mathrm{pH} 7.5,1.5 \mathrm{mmol}$ EDTA $\mathrm{Na}_{4} \mathrm{l}^{-1}, 12 \mathrm{mmol}$ monothioglycerol $\mathrm{l}^{-1}, 10 \%$ glycerol, $10 \mathrm{mmol}$ molybdic acid $1^{-1}$ ) with glass Duall tissue grinders. Homogenates were centrifuged ( $1500 \mathrm{~g}$ for $30 \mathrm{~min}$ ) to separate the nuclear pellet from the low-speed cytosol. The nuclear pellet was washed three times with $2.0 \mathrm{ml}$ of TEMG buffer followed by centrifugation for $10 \mathrm{~min}$ at $1500 \mathrm{~g}$. The nuclear pellet was resuspended at $120 \mathrm{mg} \mathrm{ml}^{-1}$ in TEMG buffer. The cytosol fraction was further centrifuged $(13000 \mathrm{~g})$ for $30 \mathrm{~min}$ before treatment with dextrancoated charcoal (DCC; $0.5 \%$ charcoal, $0.05 \%$ dextran in TEMG buffer) to remove unbound steroids. The DCC-treated supernatant was centrifuged at $105000 \mathrm{~g}$ for $\mathrm{Ih}$ to obtain a high-speed cytosol. High-speed cytosol was adjusted with TEMG buffer to a tissue concentration of $30 \mathrm{mg} \mathrm{ml}^{-1}$. Nuclear and cytosolic progesterone receptors were measured by nuclear and cytosol exchange assays (Anderson et al., 1972; Katzenellenbogen $e t$ 
(a)

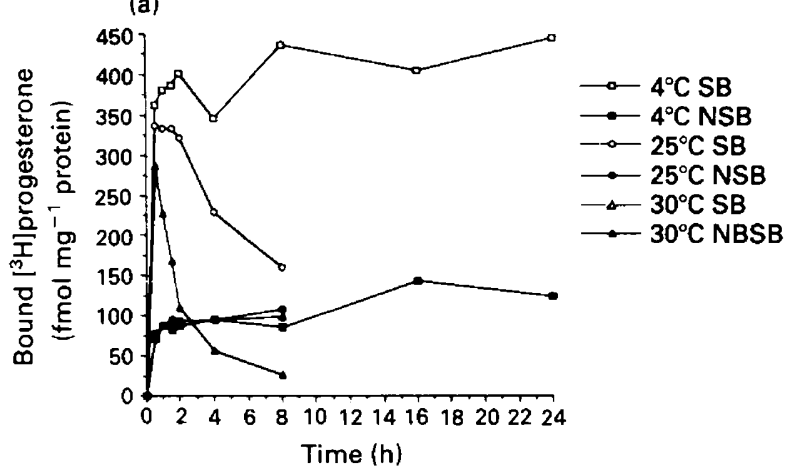

(c)

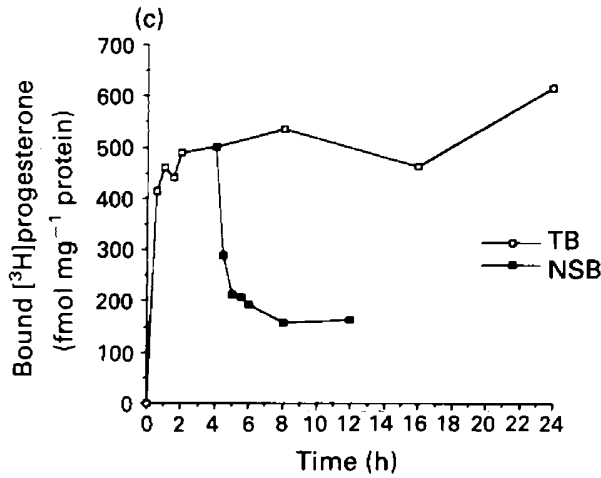

(b)

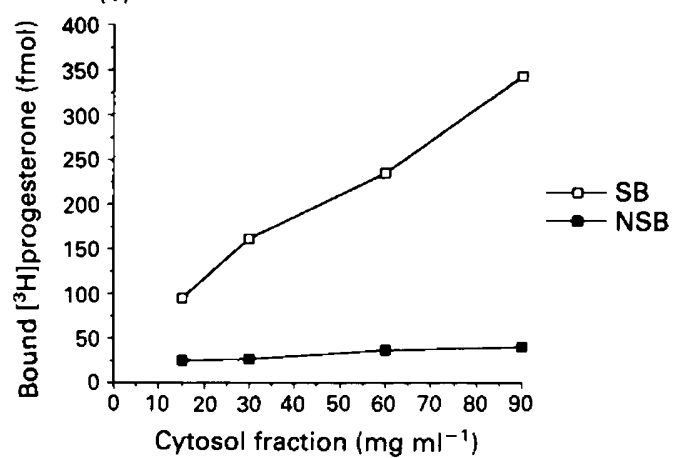

(d)

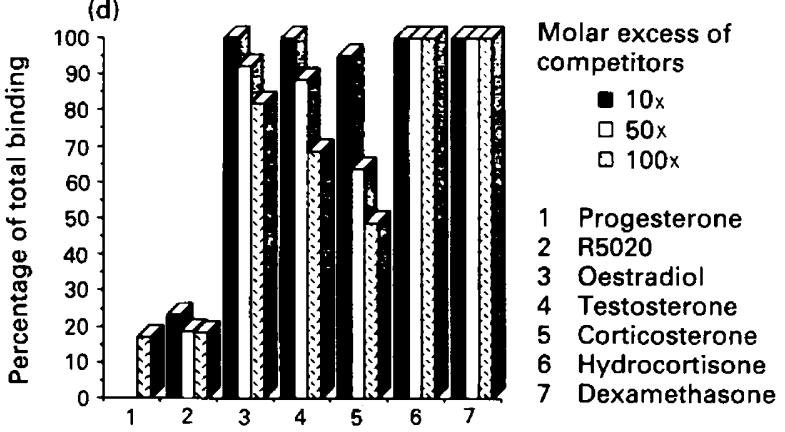

Fig. 1. Optimal conditions for measurement of bovine endometrial progesterone receptors. (a) Effects of temperature over time on $\left[{ }^{3} \mathrm{H}\right]$ progesterone binding. (b) Effects of concentration of cytosol fraction added to the assay tube on [ $\left.{ }^{3} \mathrm{H}\right]$ progesterone binding. (c) Dissociation analysis of $\left[{ }^{3} \mathrm{H}\right]$ progesterone binding in cytosol. (d) Competitive inhibition of $\left[{ }^{3} \mathrm{H}\right]$ progesterone for the progesterone receptor. SB: specific binding; NSB: nonspecific binding.

al., 1973). Both fractions were measured to account for total progesterone receptor concentration.

Cytosolic and nuclear exchange assays. Aliquots $(250 \mu \mathrm{l})$ of each fraction were added to respective assay tubes. Saturation analysis was conducted using $1-30 \mathrm{nmol} \mathrm{l}^{-1}\left[{ }^{3} \mathrm{H}\right]$ progesterone ( 9 points; New England Nuclear, Boston, MA) in the presence and absence (three tubes each) of a 100-fold molar excess of unlabelled progesterone for the nuclear fraction $\left(4 \mathrm{~h}\right.$ at $4^{\circ} \mathrm{C}$ ) and cytosolic fraction $\left(16 \mathrm{~h}\right.$ at $4^{\circ} \mathrm{C}$ ) in a total volume of $350 \mu \mathrm{l}$. Crude nuclei were washed three times to remove unbound ligand by using $1.0 \mathrm{ml}$ of TEMG buffer per tube and centrifuging for $10 \mathrm{~min}$ at $1500 \mathrm{~g}$. Subsequent to the final wash, $1.0 \mathrm{ml}$ of $100 \%$ ethanol was added to each crude nuclear pellet to solubilize nuclear-bound $\left[{ }^{3} \mathrm{H}\right]$ progesterone, and tubes were incubated for $30 \mathrm{~min}$ at $30^{\circ} \mathrm{C}$. Tubes were placed in an ice bath for $5 \mathrm{~min}$ and then centrifuged at $1500 \mathrm{~g}$ for $10 \mathrm{~min}$. After incubation, cytosol aliquots were treated with DCC to remove unbound ligand. Tubes were immediately centrifuged at $1500 \mathrm{~g}$ for $10 \mathrm{~min}$. Aliquots $(0.5 \mathrm{ml})$ of supernatant from both the nuclear and cytosolic exchange assays were measured for $\left[{ }^{3} \mathrm{H}\right]$ progesterone in a liquid scintillation counter. The protein content of high-speed cytosol was determined using the method of Lowry et al. (1951). DNA content of crude nuclei was determined by the method of Burton (1965).

Specific binding was determined as the amount of total binding minus nonspecific binding. Data were analysed according to the method of Scatchard (1949). Standard curves representing each $\left[{ }^{3} \mathrm{H}\right]$ progesterone concentration ( 1 to $30 \mathrm{nmol} \mathrm{l}^{-1}$ ) were generated and counting efficiencies estimated. Bound counts per minute were converted to fmol progesterone by correcting for counting efficiencies. Results were calculated on a receptor number per cell basis by using a value of $6.5 \mathrm{pg}$ of DNA per bovine somatic cell (Shapiro, 1970).

Validation. Optimal conditions for exchange of specific binding by progesterone receptors were determined by examining several variables using cytosol fractions prepared from endometrium of a cow on the day of oestrus (day 0 ). The optimal time and temperature incubation period for cytosol was determined as $8-24 \mathrm{~h}$ at $4^{\circ} \mathrm{C}$ (Fig. Ia).

The addition of increasing amounts of cytosol fraction resulted in an increase in $\left[{ }^{3} \mathrm{H}\right]$ progesterone bound $(95.0 \mathrm{fmol}$ at $15 \mathrm{mg} \mathrm{ml}^{-1}$ to $342.7 \mathrm{fmol}^{\text {at }} 90 \mathrm{mg} \mathrm{ml}^{-1}$ ) (Fig. Ib).

An association curve was established for progesterone receptors indicating that approximately $80-90 \%$ of maximal association with $\left[{ }^{3} \mathrm{H}\right]$ progesterone was attained by $4 \mathrm{~h}$ (Fig. 1c). After addition of unlabelled progesterone, maximum exchange was recorded by $4 \mathrm{~h}$.

Binding specificity of the progesterone receptor was established by examining the ability of a number of steroidal compounds to inhibit specific $\left[{ }^{3} \mathrm{H}\right]$ progesterone-binding (Fig. Id). All unlabelled compounds were obtained from Sigma Chemical Co. (St Louis, MO), with the exception of promegestone ( $\mathrm{R} 5020$, a synthetic progestin) which was from New England Nuclear (Boston, MA). Since the true affinities of these 
(a)

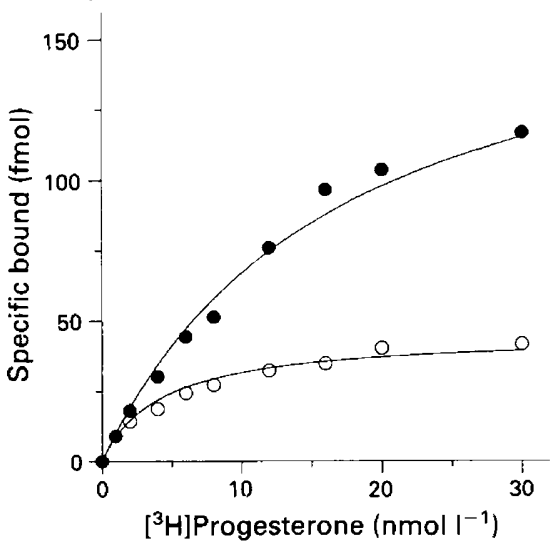

(c)

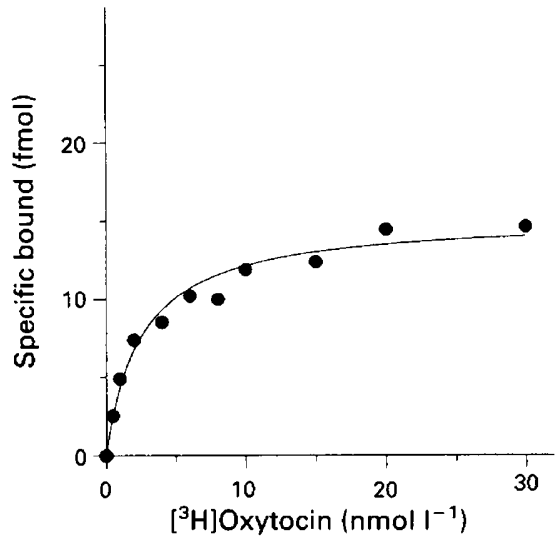

(b)

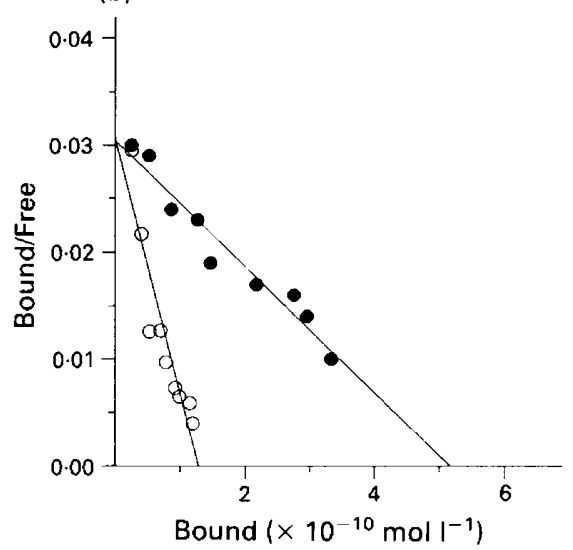

(d)

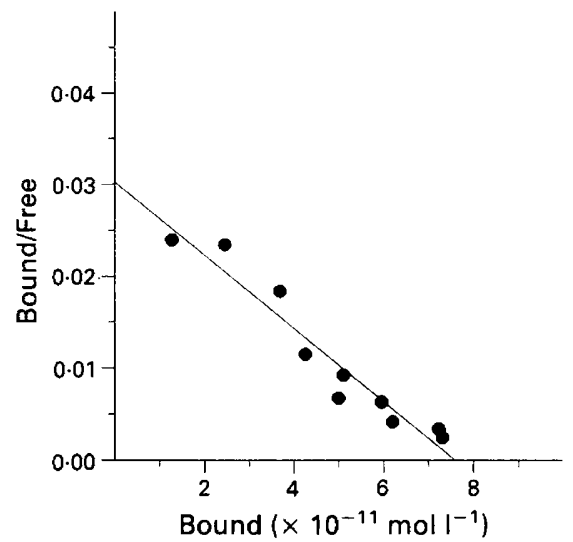

Fig. 2. Representative (a) and (c) saturation curves and (b) and (d) Scatchard analyses (right panels) of hormone-binding assays of the nuclear progesterone $(a, b)$ and membrane bound oxytocin $(c, d)$ receptors. (O) Data for the normal cycle group; and ( ) data for the short cycle group.

compounds for the progesterone receptor were not known, relative binding affinities were estimated as $100 \% \times[100 \%-\%$ binding in the presence of competitor $] /[100 \%-\%$ binding in the presence of progesterone]. Relative binding affinities exhibited by $\mathrm{R} 5020$, oestradiol, testosterone and corticosterone, when present in 100-fold molar excesses, were 98.5, 21.7, 38.1 and $61.7 \%$, respectively. Relative binding affinities of hydrocortisone and dexamethasone were each less than $1 \%$.

Under these conditions, and when measuring content of samples in which progesterone receptor concentrations were below nanomolar, saturation curves were generated and used to estimate progesterone receptor concentrations in subcellular fractions. Two saturation curves and their respective Scatchard analyses, representative of assays of cytosol and nuclei of a short cycle cow, are shown (Fig. 2a and b). Respective estimates of $K_{d}$ and $B_{\max }$ values for the assays shown were $4.2 \mathrm{nmol} \mathrm{l}^{-1}$ and $1.28 \times 10^{-10} \mathrm{~mol} \mathrm{l}^{-1}$ (for progesterone receptors in cytosol) and $16.96 \mathrm{nmol}^{-1}$ and $5.16 \times 10^{-10} \mathrm{~mol} \mathrm{l}^{-1}$ (for progesterone receptors in nuclei).

\section{Measurement of oxytocin receptors in endometrial membrane fraction}

Preparation of membrane fraction. Subcellular fractions of endometrium were prepared by the method of Sheldrick and
Flint (1985). Briefly, a sample of endometrial tissue was removed from storage at $-80^{\circ} \mathrm{C}$, minced with scissors, and allowed to thaw on ice. All subsequent procedures were conducted at $4^{\circ} \mathrm{C}$ unless noted. Tissue was homogenized using a

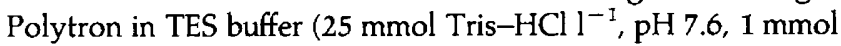
EDTA $1^{-1}, 0.25 \mathrm{~mol}$ sucrose $1^{-1}$ ). The homogenates were centrifuged at $2000 \mathrm{~g}$ for $10 \mathrm{~min}$ to remove nuclear material and then at $95000 \mathrm{~g}$ for $\mathrm{Ih}$ to pellet the membrane fraction. Pellets were resuspended by homogenization in Tris buffer (25 mmol Tris- $\mathrm{HCl} \mathrm{l}^{-1}, \mathrm{pH} 7.6$ ). Protein concentrations in the resuspended membrane fraction were determined by the method of Lowry et al. (1951). The membrane fraction was adjusted to $1-2 \mu \mathrm{g}$ protein $\mu^{-1}$.

Measurement of ${ }^{3}$ HJoxytocin binding to membrane fraction. Membrane fraction $(50 \mu \mathrm{l}=50-100 \mu \mathrm{g}$ protein) was added to each assay tube. Saturation analysis was conducted using 0.5-30 nmol $\left[{ }^{3} \mathrm{H}\right]$ oxytocin $1^{-1}$ (10 points; New England Nuclear, Boston, MA) in the presence and absence (two tubes each) of a 100-fold molar excess of unlabelled oxytocin (Sigma Chemical, St Louis, MO). After addition of all reagents, assay tubes were incubated at $25^{\circ} \mathrm{C}$ for $20 \mathrm{~min}$. After incubation, tubes were transferred to an ice bath and $2 \mathrm{ml}$ Tris-BSA buffer ( $25 \mathrm{mmol}$ Tris- $\mathrm{HCl} \mathrm{l}^{-1}, \mathrm{pH} 7.6,0.1 \%$ bovine serum albumin) 
(a)

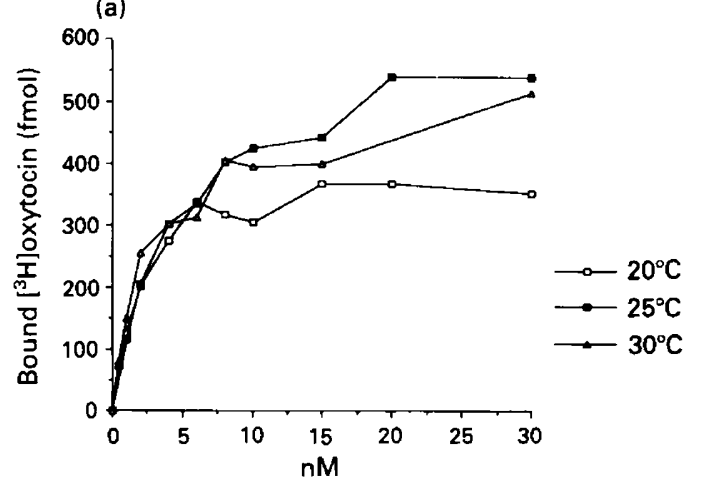

(c)

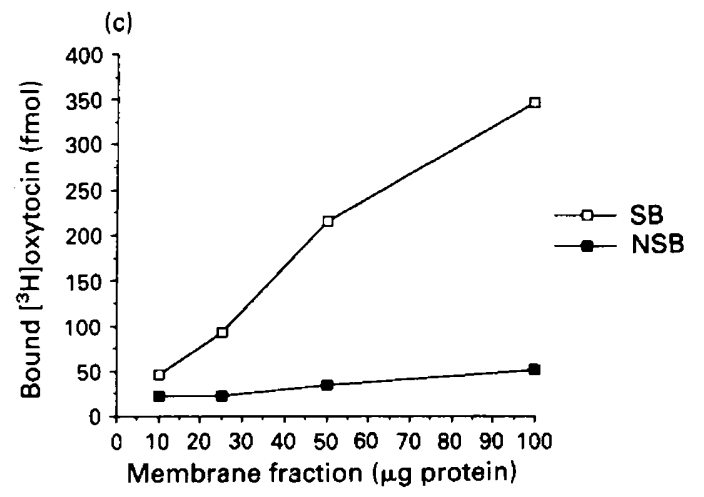

(b)
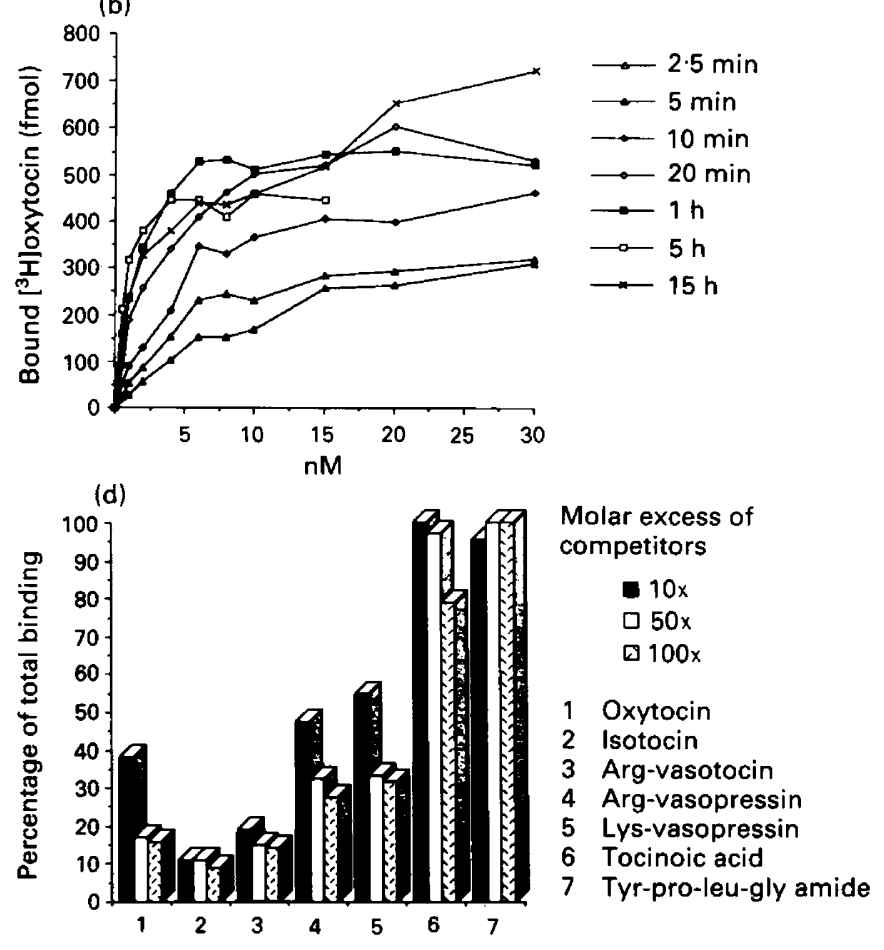

Fig. 3. Optimal conditions for measurement of bovine endometrial oxytocin receptors. (a) Effects of temperature of incubation on $\left[{ }^{3} \mathrm{H}\right]$ oxytocin binding. (b) Effects of time of incubation on $\left[{ }^{3} \mathrm{H}\right]$ oxytocin binding. (c) Effects of protein concentration of membrane fraction added to the assay tube on $\left[{ }^{3} \mathrm{H}\right]$ oxytocin binding. (d) Competitive inhibition of $\left[{ }^{3} \mathrm{H}\right]$ oxytocin for the oxytocin receptors. SB: specific binding; NSB: nonspecific binding.

was added immediately. The buffer was removed from the receptor protein by filtration onto Millipore (Millipore Corp, Bedford, MA) GVWP filters under vacuum. Filters (carrying receptor-bound $\left[{ }^{3} \mathrm{H}\right]$ oxytocin) were rinsed twice under vacuum with Tris-BSA buffer. The filters were then transferred to scintillation vials containing ethylene glycol monoethyl ether, necessary to solubilize the protein bound to the filter. Scintillation fluid was added to each vial and, after $3 \mathrm{~h}$, samples were counted for $\left[{ }^{3} \mathrm{H}\right]$ oxytocin in a liquid scintillation counter.

Specific binding was determined as the amount of total binding minus nonspecific binding. Data were analysed by Scatchard analysis (Scatchard, 1949). Counting efficiencies were estimated using standard curves which were generated from each $\left[{ }^{3} \mathrm{H}\right]$ oxytocin concentration $\left(0.5-30 \mathrm{nmol} \mathrm{l^{-1 }}\right)$. Bound c.p.m. were converted to fmol of oxytocin by correcting for counting efficiencies.

Validation. Conditions for the optimal measurement of oxytocin receptor binding were established using membrane fractions from a cow on the day of oestrus. Effects of temperature and time of incubation on specific oxytocin binding were determined as $20 \mathrm{~min}$ to $\mathrm{I} \mathrm{h}$ at $25^{\circ} \mathrm{C}$ (Fig. 3a, b).

Increasing amounts of protein resulted in an increase in $\left[{ }^{3} \mathrm{H}\right]$ oxytocin bound $(46.9 \mathrm{fmol}$ at $10 \mu \mathrm{g}$ protein to $346.2 \mathrm{fmol}$ at $100 \mu \mathrm{g}$ protein) (Fig. 3c).

Competitive inhibition of $\left[{ }^{3} \mathrm{H}\right]$ oxytocin for the oxytocin receptor was tested by using several related peptides (Sigma
Chemical Co., St Louis, MO) (Fig. 3d). Oxytocin, isotocin, $\mathrm{arg}^{8}$-vasotocin, $\mathrm{arg}^{8}$-vasopressin and lys ${ }^{8}$-vasopressin (15.8, 8.8, 14.4 and $27.6 \%$ of total binding, respectively) inhibited binding of $\left[{ }^{3} \mathrm{H}\right]$ oxytocin by oxytocin receptors. Tocinoic acid and Tyr-Pro-Leu-Gly amide did not inhibit binding of $\left[{ }^{3} \mathrm{H}\right]$ oxytocin to the oxytocin receptor.

Saturation curves were analysed by the method of Scatchard and used to estimate oxytocin receptor concentrations. A typical saturation curve and Scatchard analysis are presented (Fig. $2 \mathrm{c}$ and d). Estimates of $K_{\mathrm{d}}$ and $B_{\max }$ values for this assay were $2.51 \mathrm{nmol} \mathrm{l}^{-1}$ and $7.59 \times 10^{-11} \mathrm{~mol} \mathrm{l}^{-1}$, respectively.

\section{Statistical analyses}

Comparison of duration of oestrous cycle (short cycle versus normal cycle) was analysed by a one-tailed Student's $t$ test to determine the effects of norgestomet pretreatment (Snedecor and Cochran, 1980). In addition, statistical differences between groups for progesterone and oxytocin receptor data were ascertained by a one-tailed Student's $t$ test. Progesterone data were analysed by analysis of variance for a split-plot in time design with repeated measurements (Gill and Hafs, 1971). The general linear model included effects of treatment, time and treatment $x$ time interaction. Cow within treatment variation was used as an error term for testing treatment effects. Mean differences were ascertained using a protected least significant difference test. 


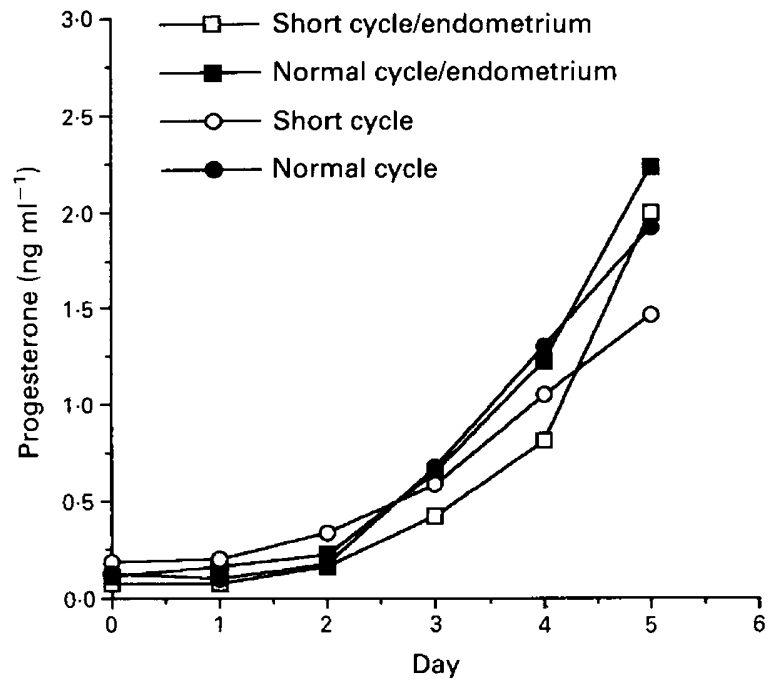

Fig. 4. Mean concentration of progesterone from day 0 to day 5 during the first postpartum oestrous cycle in beef cows. $(P>0.05$ among groups.)

\section{Results}

\section{Oestrous cycle durations and progesterone concentrations}

Oestrous cycle duration $(x \pm$ SEM) was shorter $(P<0.01)$ for the short cycle group (11.5 \pm 1.9 days) than for the normal cycle group (18.8 \pm 0.6 days). Mean concentration of progesterone was similar $(P>0.10)$ for all groups from day 0 to day 5 (Fig. 4). On day 6, mean concentration of progesterone $(x \pm$ SEM $)$ was lower $(P<0.05)$ for the short cycle group $\left(1.6 \pm 0.4 \mathrm{ng} \mathrm{m}^{-1}\right)$ than for the normal cycle group $\left(3.3 \pm 0.6 \mathrm{ng} \mathrm{ml}^{-1}\right)$. Progesterone concentration decreased thereafter to oestrus in the short cycle group and increased in the normal cycle group (peaking at $4.9 \mathrm{ng} \mathrm{ml}^{-1}$ on day 12) and remained high until luteolysis $\left(0.1 \mathrm{ng} \mathrm{ml}^{-1}\right.$ on day 18; data not shown). In addition, concentrations of progesterone were higher in all cows at the time of hysterectomy than they were on day 4. Functional luteolysis had, therefore, not begun at the time of collection of endometrial tissue.

\section{Endometrial content of progesterone receptors}

Mean number $(x \pm$ SEM) of total progesterone receptors per cell and cytosolic progesterone receptors per cell were lower $(P<0.05)$ in the short cycle/endometrium group $(67596 \pm 9367 ; 41879 \pm 7138$, respectively) than in the normal cycle/endometrium group $(97953 \pm 15042$; $74502 \pm 10389$, respectively; Fig. 5). However, numbers $(x \pm \mathrm{SEM})$ of nuclear progesterone receptors per cell were similar in the short cycle/endometrium group $(25718 \pm 3807)$ and in the normal cycle/endometrium group (21 $200 \pm 4748$; Fig. 5). The dissociation constant $\left(K_{\mathrm{d}} ; \mathrm{nmol} 1^{-1} \pm \mathrm{SEM}\right)$ estimates of progesterone receptors measured in crude nuclei were greater $(P<0.05)$ in the short cycle/endometrium group $\left(15.9 \pm 1.8 \mathrm{nmol} \mathrm{l}^{-1}\right)$ than in the normal cycle/endometrium group $\left(10.3 \pm 0.9 \mathrm{nmol} \mathrm{l}^{-1}\right)$. Estimates of $K_{d}$ values of pro-

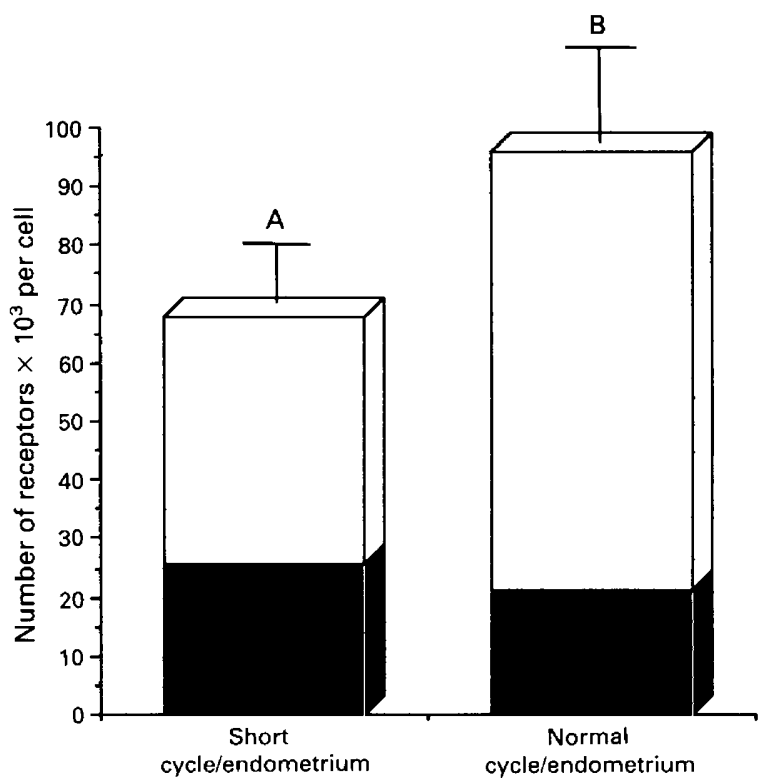

Fig. 5. Number of progesterone receptors per cell in bovine endometrial tissue on day 5 of a short or normal oestrous cycle; ( $\square$ ) cytosolic; $(\square)$ nuclear. A,B Means ( \pm SEM) having different letters are significantly different $(P<0.05)$.

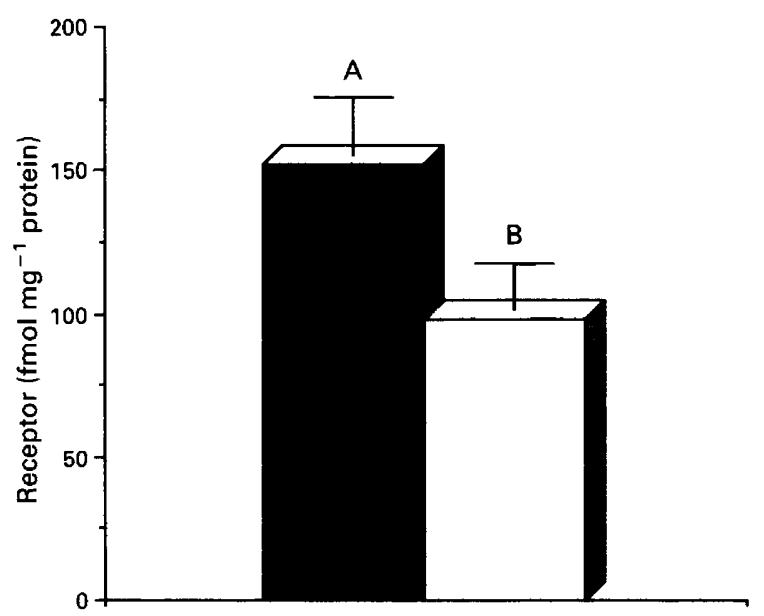

Fig. 6. Oxytocin receptor content ( $\mathrm{fmol} \mathrm{mg}^{-1}$ protein) in bovine endometrium on day 5 of a short or normal oestrous cycle. ( $\boldsymbol{\square})$ Short cycle/endometrium; ( $\square$ ) normal cycle/endometrium. A,B Means $( \pm \mathrm{SEM})$ having different letters are significantly different $(P<0.05)$.

gesterone receptors in the cytosolic fraction did not differ between the short cycle/endometrium group ( $2.9 \pm 0.2)$ and normal cycle/endometrium group $(3.0 \pm 0.2)$. The reported difference in apparent $K_{d}$ values is difficult to explain. Although the statistical difference in $K_{\mathrm{d}}$ values due to luteal status was significant, these values imply that $50 \%$ occupancy of receptors occurs when progesterone concentrations are approximately $3.2 \mathrm{ng} \mathrm{ml}^{-1}$ (for normal cows) as opposed to $4.9 \mathrm{ng} \mathrm{ml}^{-1}$ (for cows with short luteal phases). Because plasma progesterone concentrations on day 5 were between 1.5 and $2 \mathrm{ng} \mathrm{ml}^{-1}$ for 
cows in all groups, the absolute difference in per cent receptor occupancy between groups was probably small and of little biological significance. However, if such a difference occurred in conjunction with fewer progesterone receptors available for hormone binding, it would tend to render uterine target cells less responsive to effects of circulating progesterone.

\section{Endometrial content of oxytocin receptors}

Mean concentration of oxytocin receptors $(x \pm$ SEM; fmol oxytocin receptors $\mathrm{mg}^{-1}$ protein) was greater $(P<0.05)$ in the short cycle/endometrium group $(151.8 \pm 18.8)$ than in the normal cycle/endometrium group ( $98.0 \pm 17.8$; Fig. 6). In addition, estimates of $K_{d}$ values (nmol $1^{-1} \pm$ SEM) of oxytocin receptors in the short cycle/endometrium group $(2.2 \pm 0.2)$ were lower $(P<0.05)$ than in the normal cycle/endometrium group $(3.9 \pm 0.9)$.

\section{Discussion}

Pulses of oxytocin occur synchronously with pulses of $\mathrm{PGF}_{2 \alpha}$ at the time of luteolysis in cattle (Vighio and Liptrap, 1986) and sheep (Hooper et al., 1986). Oxytocin stimulates the uterus to secrete $\mathrm{PGF}_{2 \alpha}$ (Sharma and Fitzpatrick, 1974; Lafrance and Goff, 1985; Homanics and Silvia, 1988). In turn, PGF $_{2 a}$ causes release of oxytocin from the ovary (Heap et al., 1989; Lamsa et al., 1989). Thus, it has been proposed that uterine $\mathrm{PGF}_{2 \alpha}$ and luteal oxytocin develop a positive feedback loop that ensures that $\mathrm{PGF}_{2 \alpha}$ is secreted in high amplitude pulses during luteal regression (see review by Flint et al., 1990; Silvia et al., 1991).

The acquisition of uterine responsiveness to oxytocin may determine when release of $\mathrm{PGF}_{2 \alpha}$ occurs during the oestrous cycle in cattle and sheep. Uterine responsiveness to oxytocin appears to develop slowly under the influence of progesterone, and is enhanced by oestradiol (Homanics and Silvia, 1988; Lafrance and Goff, 1988; Vallet et al., 1990). Oestradiol appears to enhance uterine responsiveness to oxytocin by increasing synthesis of endometrial oxytocin receptors (Hixon and Flint, 1987). In cattle and sheep, concentrations of oxytocin receptors in endometrium are low during the mid-luteal phase and increase at the time of luteolysis until they reach peak concentrations at oestrus, a time when oestradiol concentrations are increased owing to follicular growth (Sheldrick and Flint, 1985; Jenner et al., 1991). In addition, Vallet et al. (1990) and Lau et al. (1992) suggested that progesterone and oestradiol may control factors associated with the coupling of oxytocin receptors to PGF $_{2 \alpha}$ synthesis.

Progesterone may exert a negative effect on the concentration of oxytocin receptors in uterine tissue. Progesterone blocks the ability of oestradiol to increase endometrial oxytocin receptors in rabbits (Nissenson et al., 1978) and sheep (Koligian and Stormshak, 1977). In addition, concentration of oestradiol receptors and oxytocin receptors increased in endometrium of ovariectomized ewes following progesterone withdrawal (Leavitt et al., 1985). McCracken et al. (1984) proposed that progesterone, through binding to its receptor, may inhibit synthesis of oxytocin receptors early in the oestrous cycle when the uterus is progesterone dominant. As the oestrous cycle progresses through the mid-luteal phase, concentration of progesterone receptors decreases and the uterus loses progesterone dominance. This loss allows synthesis of endometrial oestrogen receptors. Oestrogen, secreted from developing follicles, through binding to its endometrial receptor, stimulates the synthesis of endometrial oxytocin receptors. The uterus is then responsive to oxytocin and a positive feedback mechanism is established between luteal oxytocin and $\mathrm{PGF}_{2 a}$.

Oestradiol may play a role during the follicular phase to establish progesterone dominance of the uterus and, subsequently, the time of $\mathrm{PGF}_{2 \alpha}$ secretion. Oestradiol induces synthesis of endometrial progesterone receptors in vitro and in vivo in rats (Kassis et al., 1984) and sheep (Zelinski et al., 1980), respectively. Also, oestradiol increases progesterone receptors in whole uterus of ovariectomized ewes and progesterone inhibits this effect (Stone et al., 1978). Ottobre et al. (1984), therefore, suggested that the high concentrations of oestradiol associated with oestrus may induce synthesis of uterine progesterone receptors and establish the appropriate time of $\mathrm{PGF}_{2 \alpha}$ secretion. In fact, progesterone receptors in endometrium are highest at oestrus and decrease by mid-luteal phase in cows (Meyer et al., 1988) and ewes (Miller et al., 1977).

Results of the study reported here suggest that the uterus may lose progesterone dominance and be more responsive in terms of $\mathrm{PGF}_{2 a}$ secretion on day 5 of a short oestrous cycle. In the present study, the concentration of endometrial progesterone receptors was greater on day 5 of a normal oestrous cycle than on day 5 of a short oestrous cycle. In addition, the concentration of oxytocin receptors was lower in endometrium on day 5 of a normal oestrous cycle versus a short oestrous cycle.

After exposure of the uterus post partum to progesterone, the first ovulation is followed by normal luteal function. At this time, there is no evidence to implicate a direct effect of progesterone priming on secretion of $\mathrm{PGF}_{2 a}$ during the subsequent cycle. However, progestogen pretreatment may indirectly coordinate timing of $\mathrm{PGF}_{2 \alpha}$ release during the subsequent oestrous cycle by altering endometrial oxytocin receptor concentrations. Progesterone priming of ovariectomized ewes followed by oestradiol replacement for 2 days and then exogenous progesterone for 5 days decreased oxytocin receptor concentrations compared with non-primed ewes receiving oestradiol for 2 days followed by progesterone for 5 days (Vallet et al., 1990). Oestradiol further enhanced endometrial oxytocin receptor concentrations in primed and non-primed ewes when administered on days 4 and 5 of progesterone treatment. In addition, oxytocin induced an increase in plasma concentrations of PGFM only in ewes that did not receive progestagen pretreatment and subsequently received progesterone treatment for 5 days and oestradiol treatment on days 4 and 5 (Vallet et al, 1990). In addition, Hunter (1991) reported that although concentration of endometrial oxytocin binding sites was high on day 1 , they were similar to those of anoestrous ewes expected to have a short versus normal luteal phase. However, on days 3 and 5 , numbers of endometrial oxytocin receptors were greater in ewes having a short oestrous cycle compared with a normal oestrous cycle. In this study, numbers of endometrial oxytocin receptors were greater on day 5 of cows expected to have a short luteal phase than in cows receiving progestogen pretreatment and expected to have 
a normal luteal phase. These results suggest that progesterone priming enhances the effect of subsequent progesterone on inhibition of oxytocin receptor concentrations in endometrium and therefore decreases uterine responsiveness to oxytocin.

Concentration of oestradiol in serum was lower at oestrus in cows exhibiting a subsequent short versus normal luteal phase (Garcia-Winder et al., 1986; Garverick et al., 1988). The role oestradiol plays before ovulation in determining subsequent luteal lifespan is not clear. Prolonged exposure to exogenous oestradiol during the postpartum interval extended luteal lifespan following first ovulation in beef cows (Day et al., 1990). Conversely, inhibition of synthesis of oestradiol prior to ovulation did not result in subfunctional corpora lutea but delayed oestrus and onset of the luteal phase in sheep (Benoit $e t$ al., 1991). The increase in oestradiol around ovulation in cows receiving progesterone priming may be a direct result of the progestogen pretreatment used in these studies. However, since increased concentrations of oestradiol have been associated with induction of a full complement of endometrial progesterone receptors required for progesterone dominance of the uterus (Zelinski et al., 1980), the decreased concentrations of oestradiol preceding ovulation of a short oestrous cycle may have resulted in decreased progesterone receptor synthesis leading to a loss of uterine progesterone dominance earlier following ovulation.

In conclusion, concentrations of progesterone receptors in endometrium was greater on day 5 in cows having a normal oestrous cycle rather than a short oestrous cycle. In addition, concentration of oxytocin receptors in endometrium was lower in cows having a normal versus a short luteal phase. Thus, the uterus may lose progesterone dominance at an earlier time during a short oestrous cycle. This would allow the synthesis of oxytocin receptors and initiate the positive feedback loop between oxytocin and $\mathrm{PGF}_{2 \alpha}$ which leads to a premature release of $\mathrm{PGF}_{2 \alpha}$.

Contribution from the Missouri Agricultural Experiment Station Journal Series No. 11,581. This research was partially supported by USDA Grant, USDA CSRS 90-37240-5777.

\section{References}

Anderson JN, Clark JH and Peck EJ, Jr (1972) Oestrogen and nuclear binding sites: determination of specific sites by $\left[{ }^{3} \mathrm{H}\right]$-oestradiol exchange Biochemical Joumal 126 561-567

Benoit AM, Inskeep EK and Dailey RA (1991) Inhibition of follicular phase secretion of estradiol delays onset of the luteal phase in ewes Joumal of Animal Science 69 (Supplement 1), 443

Berardinelli JG, Dailey RA, Butcher RL and Inskeep EK (1980) Source of circulating progesterone in prepubertal ewes Biology of Reproduction 22 233-236

Burton K (1965) A study of the conditions and mechanism of the diphenylamine reaction for the colorimetric estimation of deoxyribonucleic acid Biochemical Joumal 62 315-322

Cooper DA, Carver DA, Villeneuve P, Silvia WJ and Inskeep EK (1991) Effects of progestogen treatment on concentrations of prostaglandins and oxytocin in plasma from the posterior vena cava of post-partum beef cows journal of Reproduction and Fertility 91 411-421

Copelin JP, Smith MF, Garverick HA and Youngquist RS (1987) Effect of the uterus on subnormal luteal function in anestrous beef cows Joumal of Animal Science 64 1506-1511

Copelin JP, Smith MF, Keisler DH and Garverick HA (1989) Effect of active immunization of prepartum and postpartum cows against prostaglandin $F_{20}$ on lifespan and progesterone secretion of short-lived corpora lutea Journal of Reproduction and Fertility 87 199-207

Day ML, Dyer RM, Wilson GW and Pope WF (1990) Influence of estradiol on duration of anestrus and incidence of short estrous cycles in postpartum cows Domestic Animal Endocrinology 7 19-25

Flint APF, Sheldrick EL, McCann TJ and Jones DSC (1990) Luteal oxytocin: characteristics and control of synchronous episodes of oxytocin and $\mathrm{PGF}_{2 a}$ secretion at luteolysis in ruminants Domestic Animal Endocrinology 7 111-124

Garcia-Winder M, Lewis PE, Deaver DR, Smith VG, Lewis GS and Inskeep EK (1986) Endocrine profiles associated with life span of induced corpora lutea in postpartum beef cows Joumal of Animal Science 62 1353-1362

Garverick HA and Smith MF (1986) Mechanisms associated with subnormal luteal function Joumal of Animal Science 62 (Supplement 2), 92-105

Garverick HA, Parfet JR, Lee CN, Copelin JP, Youngquist RS and Smith MF (1988) Relationship of pre- and post-ovulatory gonadotropin secretion to subnormal luteal function in postpartum beef cattle joumal of Animal Science $66104-111$

Gasc J-M, Renoir J-M, Radanji C, Joab L, Tuohimma P and Baulieu E-E (1984) Progesterone receptor in the chick oviduct: an immunohistochemical study with antibodies to distinct receptor components Joumal of Cell Biology 99 1193-1202

Gill JL and Hafs HD (1971) Analysis of repeated measurements of animals Joumal of Animal Science 33 331-336

Gonzalez-Padilla E, Niswender GD and Wiltbank JN (1975) Puberty in beef heifers: II. Effect of injections of progesterone and estradiol-17 $\beta$ on serum LH, FSH and ovarian activity Journal of Animal Science 40 1105-1109

Haresign W, Foster JP, Haynes NB, Crighton DB and Lamming GE (1975) Progesterone levels following treatment of seasonally anoestrous ewes with synthetic LH-releasing hormone Journal of Reproduction and Fertility $\mathbf{4 3}$ 269-279

Heap RB, Fleet IR, Davis AJ, Goode JA, Hamon MH, Walters DE and Flint APF (1989) Neurotransmitters and lymphatic vascular transfer of prostaglandin $F_{2 \alpha}$ stimulate ovarian oxytocin output in sheep Joumal of Endocrinology 122 $147-159$

Hixon JE and Flint APF (1987) Effects of a luteolytic dose of oestradiol benzoate on uterine oxytocin receptor concentrations, phosphoinositide turnover and prostaglandin $\mathrm{F}_{2 a}$ secretion in sheep Journal of Reproduction and Fertility $\mathbf{7 9}$ $457-467$

Homanics GE and Silvia WJ (1988) Effects of progesterone and estradiol-17 $\beta$ on uterine secretion of prostaglandin $F_{2 a}$ in response to oxytocin in ovariectomized ewes Biology of Reproduction 38 804-811

Hooper SB, Watkins WB and Thorburn GD (1986) Oxytocin, oxytocinassociated neurophysin, and prostaglandin $F_{2 a}$ concentrations in the utero-ovarian vein of pregnant and nonpregnant sheep Endocrinology 119 2590-2597

Hunter MG (1991) Characteristics and causes of the inadequate corpus luteum Joumal of Reproduction and Fertility Supplement 43 91-99

Hunter MG, Ayad VJ, Gilbert CL, Southee JA and Wathes DC (1989) Role of prostaglandin $\mathrm{F}_{2 a}$ and oxytocin in the regression of $\mathrm{GnRH}$-induced abnormal corpora lutea in anestrous ewes Journal of Reproduction and Fertility 85 $551-561$

Jenner LJ, Parkinson TJ and Lamming GE (1991) Uterine oxytocin receptors in cyclic and pregnant cows Journal of Reproduction and Fertility 91 49-58

Kassis JA, Sakai D, Walent JH and Gorski J (1984) Primary cultures of estrogenresponsive cells from rat uteri: induction of progesterone receptors and a secreted protein Endocrinology 114 1558-1566

Katzenellenbogen JA, Johnson HJ and Carlson KE (1973) Studies on the uterine, cytoplasmic estrogen binding protein. Thermal stability and ligand dissociation rate. An assay of empty and filled sites by exchange Biochemistry 12 4092-4099

Keisler DH, Inskeep EK and Dailey RA (1983) First luteal tissue in ewe lambs: influence on subsequent ovarian activity and response to hysterectomy Journal of Animal Science 57 150-156

King WJ and Greene GL (1984) Monoclonal antibodies localize oestrogen receptor in the nuclei of target cells Nature 307 745-747

Koligian KB and Stormshak F (1977) Progesterone inhibition of estrogen receptor replenishment in ovine endometrium Biology of Reproduction 17 $412-416$

Lafrance $M$ and Goff AK (1985) Effects of pregnancy on oxytocin-induced release of prostaglandin $\mathrm{F}_{2 \alpha}$ in heifers Biology of Reproduction 33 1113-1119

Lafrance $M$ and Goff AK (1988) Effects of progesterone and estradiol-17 $\beta$ on oxytocin-induced release of prostaglandin $\mathrm{F}_{2 a}$ in heifers Journal of Reproduction and Fertility 82 429-436 
Lamsa JC, Kot SJ, Eldering JA, Nay MG and McCracken JA (1989) Prostaglandin $\mathrm{F}_{2 \mathrm{a}}$-stimulated release of ovarian oxytocin in the sheep in vitro: threshold and dose dependency Biology of Reproduction 40 1215-1223

Lau TM, Gow CB and Fairclough RJ (1992) Differential effects of progesterone treatment on the oxytocin-induced prostaglandin $F_{2 a}$ response and the levels of endometrial oxytocin receptors in ovariectomized ewes Biology of Reproduction 46 17-22

Leavitt WW, Okulicz WC, McCracken JA, Schramm W and Robidone WF (1985) Rapid recovery of nuclear estrogen receptor and oxytocin receptor in the ovine uterus following progesterone withdrawal Joumal of Steroid Biochemistry 22 687-691

Lishman AW and Inskeep EK (1991) Deficiencies in luteal function during re-initiation of cyclic breeding activity in beef cows and in ewes South African joumal of Animal Science 21 59-76

Lowry OH, Rosebrough NJ, Farr AL and Randall RJ (1951) Protein measurement with the Folin phenol reagent Journal of Biological Chemistry $193265-275$

McCracken JA, Schramm W and Okulicz WC (1984) Hormone receptor control of pulsatile secretion of $\mathrm{PGF}_{2 a}$ from the ovine uterus during luteolysis and its abrogation in early pregnancy Animal Reproduction Science 7 31-55

Meyer HHD, Mittermeier Th and Schams D (1988) Dynamics of oxytocin, estrogen and progestin receptors in the bovine endometrium during the estrous cycle Acta Endocrinologica 118 96-104

Miller BG, Murphey L and Stone GM (1977) Hormone receptor levels and hormone, RNA and protein metabolism in the genital tract during the oestrous cycle of the ewe Journal of Endocrinology 73 91-98

Nissenson R, Flouret G and Hechter $O$ (1978) Opposing effects of estradiol and progesterone on oxytocin receptors in rabbit uterus Proceedings National Academy of Sciences, USA 75 2044-2048

Odde KG, Wood HS, Kiracofe GH, McKee RM and Kittock RJ (1980) Short estrous cycles and associated serum progesterone levels in beef cows Theriogenology 14 105-112

Ottobre JS, Vincent DL, Silvia WJ and Inskeep EK (1984) Aspects of regulation of uterine secretion of prostaglandins during the oestrous cycle and early pregnancy Animal Reproduction Science 7 75-100

Ramirez-Godinez JA, Kiracofe GH, McKee RM, Schalles RR and Kittock RJ (1981) Reducing the incidence of short estrous cycles in beef cows with norgestomet Theriogenology 15 613-623

Scatchard G (1949) The attraction of proteins for small molecules and ions Annals of the New York Academy of Science 51 660-672
Shapiro H (1970) Deoxyribonucleic acid content per cell of various organisms. In Handbook of Biochemistry: Selected Data for Molecular Biology pp 112-114. Ed. HA Sober. The Chemical Rubber Co., Cleveland

Sharma SC and Fitzpatrick RJ (1974) Effects of oestradiol-17 $\beta$ on the release of prostaglandin $\mathrm{F}_{2}$ alpha release in the anoestrous ewe Prostaglandins 6 97-105

Sheldrick EL and Flint APF (1985) Endocrine control of uterine oxytocin receptors in the ewe Journal of Endocrinology 106 249-258

Silvia WJ, Lewis GS, McCracken JA, Thatcher WW and Wilson L, Jr (1991) Hormonal regulation of uterine secretion of prostaglandin $F_{2 a}$ during luteolysis in ruminants Biology of Reproduction 45 655-663

Snedecor GW and Cochran WG (1980) Statistical Methods (7th Ed). Iowa State University Press, Ames

Southee JA, Hunter MG, Law AS and Haresign W (1988) Effect of hysterectomy on the short life-cycle corpus luteum produced after $\mathrm{GnRH}$-induced ovulation in the anoestrous ewe Joumal of Reproduction and Fertility 84 149-155

Stone GM, Murphey L and Miller BG (1978) Hormone receptor levels and metabolic activity in the uterus of the ewe: regulation by oestradiol and progesterone Australian Joumal of Biological Science 31 395-403

Vallet IL, Lamming GE and Batten M (1990) Control of endometrial oxytocin receptor and uterine response to oxytocin by progesterone and oestradiol in the ewe Journal of Reproduction and Fertility 90 625-634

Vighio GH and Liptrap RM (1986) Plasma concentrations of oxytocin, prostaglandin and ovarian steroids during spontaneous luteolysis in the cow Domestic Animal Endocrinology 3 209-215

Welshons WV, Krummel BN and Gorski J (1985) Nuclear localization of unoccupied receptors for glucocorticoids, estrogens, and progesterone in $\mathrm{GH}_{3}$ cells Endocrinology 117 2140-2147

Zelinski MB, Hirota NA, Keenan EJ and Stormshak F (1980) Influence of exogenous estradiol-17 $\beta$ on endometrial progesterone and estrogen receptors during the luteal phase of the ovine estrous cycle Biology of Reproduction 23 743-751

Zollers WG, Jr, Garverick HA and Smith MF (1989) Oxytocin-induced release of prostaglandin $\mathrm{F}_{2 \mathrm{a}}$ in postpartum beef cows: comparison of short versus normal luteal phases Biology of Reproduction 41 262-267

Zollers WG, Jr, Garverick HA, Youngquist RS, Ottobre JS, Silcox RW, Copelin JP and Smith MF (1991) In vitro secretion of prostaglandins from endometrium of postpartum beef cows expected to have short or normal luteal phases Biology of Reproduction 44 522-526 